International Journal of Pure and Applied Mathematics

Volume 110 No. 2 2016, 361-368

ISSN: 1311-8080 (printed version); ISSN: 1314-3395 (on-line version)

url: http://www.ijpam.eu

doi: 10.12732 /jpam.v110i2.10

ijpam.eu

\title{
MATHEMATICAL JUSTIFICATION OF THE SELECTION OF WOODY PLANTS BIODIVERSITY IN THE RECONSTRUCTION OF OBJECTS OF GARDENING
}

\author{
A.V. Semenyutina ${ }^{1 \S}$, I.Y. Podkovyrov ${ }^{2}$, \\ A.Sh. Huzhahmetova ${ }^{3}$, V.A. Semenyutina ${ }^{4}$, G.V. Podkovyrova ${ }^{5}$ \\ 1,2,3,4,5 Russian Research Institute of Agroforestry \\ 400062, University Ave. 97, Volgograd, RUSSIAN FEDERATION \\ ${ }^{2}$ Volgograd State Agrarian University \\ 400002, University Ave. 26, Volgograd, RUSSIAN FEDERATION
}

\begin{abstract}
The article gives a mathematical justification of the results of years of research on the selection of tree species biodiversity. On the basis of experimental data the purposed mathematical model of expansion of the species diversity of tree species for the reconstruction of gardening objects. It is a differential equation that allows you to prove mathematically the number of species in the solution of the problem of increasing plant biodiversity.
\end{abstract}

AMS Subject Classification: 2H05, 35N05

Key Words: differential equation, mathematical modeling, biodiversity, woody plants, planting sites

\section{Introduction}

Numerous data published in the literature [1] and [2] with varying degrees of accuracy show the possibility of using linear functions. They are recommended for the analysis of the dynamics of species diversity of woody plants in the reconstruction of objects of gardening (planting, street, squares, parks) [3] and [4].

Received: $\quad$ September 17, 2016

Revised: $\quad$ October 4, 2016

Published: November 4, 2016

(c) 2016 Academic Publications, Ltd.

url: www.acadpubl.eu

$\S_{\text {Correspondence author }}$ 
Due to the fact that the species composition of green space varies in space and time, linear functions do not take into account the biological processes that determine the development of plantations [5] and [6]. We propose a mathematical modeling method of differential equations, developed on the basis of experimental data copyright [7] and [8]. Climatic exposure, age specificity and edaphic conditions take into account the direction of the process of selection of biodiversity species [9].

Mathematical justification of the selection of woody plant diversity held for the reconstruction of gardening objects within the Volgograd agglomeration (see Table 1).

\begin{tabular}{|c|c|c|c|c|c|}
\hline \multirow[t]{3}{*}{ Indicators } & \multicolumn{5}{|c|}{ Greening plantings } \\
\hline & \multicolumn{4}{|c|}{ of limited use } & \multirow{2}{*}{$\begin{array}{l}\text { of common } \\
\text { use } \\
\text { boulevard }\end{array}$} \\
\hline & $\begin{array}{l}\text { park } \\
\text { of the } \\
\text { agrarian } \\
\text { University }\end{array}$ & schoolyard & $\begin{array}{l}\text { plantings } \\
\text { of the } \\
\text { hospital } \\
\text { complex }\end{array}$ & $\begin{array}{l}\text { intraquater } \\
\text { landing }\end{array}$ & \\
\hline $\begin{array}{l}\text { Year book- } \\
\text { marks }\end{array}$ & 1948 & 1975 & 1975 & 1948 & 1975 \\
\hline Area, acre & 32 & 1,62 & 1,9 & 0,16 & 5,5 \\
\hline $\begin{array}{l}\text { The number } \\
\text { of species } \\
\text { of woody } \\
\text { plants }\end{array}$ & 19 & 15 & 22 & 17 & 18 \\
\hline $\begin{array}{l}\text { (main } \\
\text { species) }\end{array}$ & $\begin{array}{l}\text { (Ulmus } \\
\text { pumila, } \\
\text { Robinia } \\
\text { pseudoa- } \\
\text { cacia, } \\
\text { Fraxinus } \\
\text { pennsyl- } \\
\text { vanica) }\end{array}$ & $\begin{array}{l}\text { (Ulmus } \\
\text { pumila, } \\
\text { Populus } \\
\text { pyra- } \\
\text { midali, } \\
\text { Populus } \\
\text { deltoides) }\end{array}$ & $\begin{array}{l}\text { (Pinus } \\
\text { sylvestris, } \\
\text { Betula } \\
\text { pendula, } \\
\text { Aesculus } \\
\text { hippocas- } \\
\text { tanum) }\end{array}$ & $\begin{array}{l}\text { (Fraxinus } \\
\text { pennsyl- } \\
\text { vanica, } \\
\text { Ulmus } \\
\text { pumila, } \\
\text { Robinia } \\
\text { pseudoa- } \\
\text { cacia) }\end{array}$ & $\begin{array}{l}\text { (Ulmus } \\
\text { pumila, } \\
\text { Catalpa } \\
\text { bignon- } \\
\text { ioides, } \\
\text { Populus } \\
\text { balsamifer) }\end{array}$ \\
\hline
\end{tabular}

Table 1: Characteristics of objects of research in 2016

\section{Preliminaries}

An analysis of the dynamics of species diversity was conducted at research objects from 1950 to 2016 with the use of departmental materials and method 
of visual inspection of plant instances. In determining the plant age was used special instruments [10], [11], [12], [13], [14], [15] and [6]. In order to identify patterns of change in species composition of plants used differential growth equation [16]:

$$
\frac{d x}{d t}=a-b x^{2}
$$

where

$$
a=\frac{\lambda-\beta}{3 \delta \rho} ; \quad b=\frac{\gamma}{3 \delta \rho} ; \quad a>0, \quad b>0, \quad x^{2}<\frac{a}{b} ;
$$

$\alpha, \beta, \gamma, \delta$ - constants characterizing the quantitative variety of woody plants;

$\chi$ - the number of woody species in plantations;

$t$ - age of the plantations;

$\rho$ - the number of specimens of plants.

\section{Results}

From equation (1) we get $d t=\frac{d x}{a-b x^{2}}$ and after integrating the will have:

$$
t=\int \frac{d x}{a-b x^{2}}=-\frac{1}{2 \sqrt{a b}} \ln \frac{a-x \sqrt{a b}}{a+x \sqrt{a b}}+C,
$$

where $C$ is constant of integration.

From equation (3) we get

$$
-2 \sqrt{a b}(t-C)=\ln \frac{a-x \sqrt{a b}}{a+x \sqrt{a b}}
$$

or

$$
e^{-2^{\sqrt{ }} \overline{a b}(t-C)}=\frac{a-x \sqrt{a b}}{a+x \sqrt{a b}}
$$

From equation (4) we have

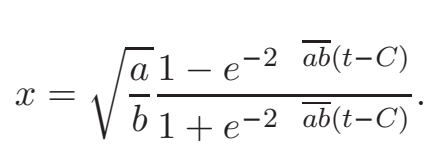

Change curves shown the number of species in the graph (see Figure 1).

On the basis of the curve obtained from experimental data of increasing the number woody species on time defined three constants equations (5) $a, b, c$. From the equation (5) the calculated curve was calculated and its received good coincidence with the experimental curve in every intermediate points. 


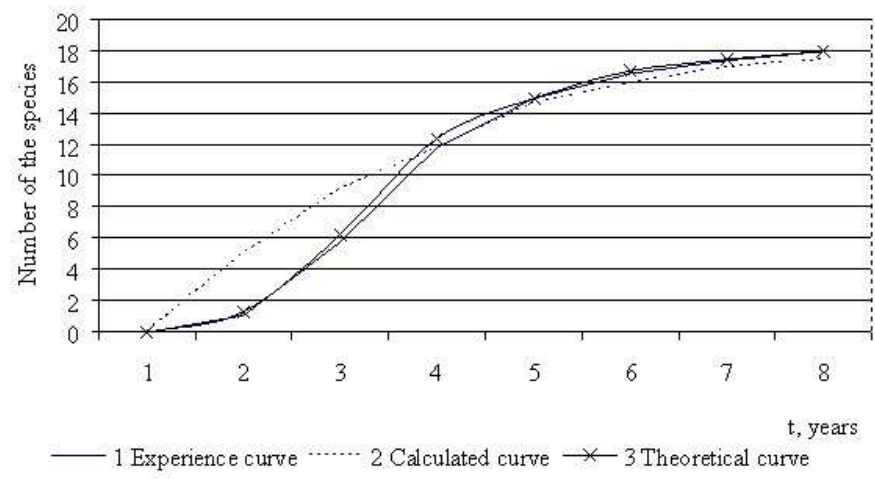

Figure 1: Dynamics on the number of woody plants species in the age aspect of gardening objects

However, an attempt to superimpose thus calculated curve to another curve found not too good coincidence (Figure 1). In Figure 1, the curve drawn by a solid line corresponds to experimental data. As seen, in a first half of the graph calculated curve gives higher values of the number of plant species, in the second half - a few understated. If the determination of the constants equations (5) $a, b$ and $c$ select points on the part of the experimental curve, the calculation yields relatively good coincidence theoretical and experimental curves.

Let us choose as a reference point points with coordinates $(t, x 1),(2 t, x 2)$, $(3 t, x 3)$.

Having substituted the coordinates of the selected points in the equation (5), we obtain a system of transcendental equations for the unknown constants $a, b$ and $c$ :

$$
\begin{aligned}
& x_{1}=\sqrt{\frac{a}{b}} \cdot \frac{1-e^{-2^{\sqrt{ }} \overline{a b}(t-C)}}{1+e^{-2} \overline{a b}(t-C)}, \quad x_{2}=\sqrt{\frac{a}{b}} \cdot \frac{1-e^{-2^{\sqrt{ }} \overline{a b}(2 t-C)}}{1+e^{-2} \overline{a b}(2 t-C)}, \\
& x_{3}=\sqrt{\frac{a}{b}} \cdot \frac{1-e^{-2^{\sqrt{ }} \overline{a b}(3 t-C)}}{1+e^{-2} \overline{\overline{a b}}(3 t-C)} .
\end{aligned}
$$

Transforming the equation (6) as follows:

$$
\begin{aligned}
& x_{1}=\sqrt{\frac{a}{b}} \cdot \frac{e^{2^{\sqrt{ }} \overline{a b} t}-e^{2^{\sqrt{ }} \overline{a b} C}}{e^{2^{\sqrt{a b}} t}+e^{2^{\sqrt[a b]{ }} C}}, \\
& x_{2}=\sqrt{\frac{a}{b}} \cdot \frac{e^{4^{\sqrt{ }} \overline{a b} t}-e^{2^{\sqrt{ }} \overline{a b} C}}{e^{4} \overline{a b} t+e^{2} \overline{a b} C},
\end{aligned}
$$




$$
x_{3}=\sqrt{\frac{a}{b}} \cdot \frac{e^{6^{\sqrt{ }} \overline{a b} t}-e^{2^{\sqrt{ }} \overline{a b} C}}{e^{6} \overline{a b} t}+e^{2^{\sqrt[a b]{ }} C} .
$$

Introduce the notation

$$
e^{2^{\sqrt{ }} \overline{a b} t}=s ; e^{2^{\sqrt{a b}} C}=q,
$$

After that the system (7) takes the form:

$$
x_{1}=\sqrt{\frac{a}{b}} \cdot \frac{s-q}{s+q} ; x_{2}=\sqrt{\frac{a}{b}} \cdot \frac{s^{2}-q}{s^{2}+q} ; x_{3}=\sqrt{\frac{a}{b}} \cdot \frac{s^{3}-q}{s^{3}+q} ;
$$

By dividing left and right sides of the equations (9) of the first on the second and the first on the third and introducing the notation

$$
\frac{x_{1}}{x_{2}}=\eta_{1} ; \frac{x_{1}}{x_{3}}=\eta_{2}
$$

we get

$$
\eta_{1}=\frac{(s-q)\left(s^{2}+q\right)}{(s+q)\left(s^{2}-q\right)} ; \eta_{2}=\frac{(s-q)\left(s^{3}+q\right)}{(s+q)\left(s^{3}-q\right)} ;
$$

After a bit of transformations, having arranged the left side of equations in powers of $q$, we will have

$$
\begin{gathered}
\left(1-\eta_{1}\right) s^{3}-\left(1+\eta_{1}\right)\left(s^{2}-s\right) q-\left(1-\eta_{1}\right) q^{2}=0 \\
\left(1-\eta_{2}\right) s^{4}-\left(1+\eta_{2}\right)\left(s^{3}-s\right) q-\left(1-\eta_{2}\right) q^{2}=0 .
\end{gathered}
$$

We eliminate $q$ from the system of equations (12) (using the determinant of Sylvester) [16] and [17], we obtain the equation with respect to $s$ :

$$
\left|\begin{array}{cccc}
\left(1-\eta_{1}\right) s^{3} & -\left(1+\eta_{1}\right)\left(s^{2}-s\right) & -\left(1-\eta_{1}\right) & 0 \\
0 & \left(1-\eta_{1}\right) s^{3} & -\left(1+\eta_{1}\right)\left(s^{2}-s\right) & -\left(1-\eta_{1}\right) \\
\left(1-\eta_{2}\right) s^{4} & -\left(1+\eta_{2}\right)\left(s^{3}-s\right) & -\left(1-\eta_{2}\right) & 0 \\
0 & \left(1-\eta_{2}\right) s^{4} & -\left(1+\eta_{2}\right)\left(s^{3}-s\right) & -\left(1-\eta_{2}\right)
\end{array}\right|=0
$$

We rotate the determinant on the left side of the equation (13) and introduce the notation

$$
\frac{1+\eta_{1}}{1-\eta_{1}}=m_{1} ; \frac{1+\eta_{2}}{1-\eta_{2}}=m_{2}
$$

After some elementary transformations we obtain a quadratic equation with respect to $s$ :

$$
s^{2}+\frac{\left(m_{2}-m_{1}\right)^{2}+m_{2}^{2}-1}{m_{2}\left(m_{2}-m_{1}\right)} s+1=0 .
$$


Let us take value of the number of species in selected experimental curve (Fig 1.) corresponding to the time $t=25,50$ and 75 years:

$$
\begin{array}{cc}
\text { Age, years } & , \text { species } \\
t=25 & 9,78(10 \text { species }) \\
2 t=50 & 18,5(19 \text { species }) \\
3 t=75 & 20,5(21 \text { species })
\end{array}
$$

By substituting numeric values in the formula (10) and (14), and then equation (15), shall solve this equation and shall find the two value of the quantity $s: s_{1}=0,17 ; s_{2}=5,95$.

The first one found, we must discard the, as $s=e^{2^{\sqrt{ }} \overline{a b} t}$ and therefore, $s>1$.

To find the values of the unknown quantity of $q$, we use one of the equations (12), from which we get $q_{1}=2,06 ; q_{2}=-95,5$.

A negative value of $q$ discard for reasons similar to those that have been taken at a choice the values $s$.

By equation (8), we find the value $\sqrt{a b}$ and $c$ :

From the first equation (9) we get $\sqrt{a / b}=20,82$.

To obtain of the theoretical curve, we substitute into the equation (5) the obtained values $\sqrt{a b}, \sqrt{a / b}$ and $c$ and define a the value of the number of species of woody plants $x$ for the time values $t=15,20,25 \ldots 75$ years, after which put the point with the corresponding coordinates on a graph (Fig. 1). The same graph shows the experimental curve. As seen, the coincidence of the two curves is quite good.

\section{Conclusion}

Thus, the work carried out demonstrates the prospect of analytical mathematical models in justifying the selection of tree species biodiversity for the reconstruction of gardening objects. Discovered regularities can significantly expand the information obtained by direct observation, extrapolation of the observed processes in the past and the future and outline the direction of new experiments.

\section{Acknowledgments}

We are very grateful to Doctor of Technical Sciences, Professor of the Department of Applied Mathematics and Fundamentals of Scientific Researches of 
Volgograd State Agricultural University Alexey Fruminovich Rogachev for his valuable support and consulting.

\section{References}

[1] I.P. Svintsov, Forest Melioration of Sandy Deserts of Turkmenistan, Ashgabat (1988).

[2] I.P. Svintsov, V.A. Semenyutina, The Methodological Foundations for the Study of Plant Organisms in the Conditions of Introduction, Modern Science: Actual Problems of Theory and Practice. Series of Natural and Technical Sciences, 9-10 (2014), 42-47.

[3] A.V. Semenyutina et al., Scientific Guidelines for Optimization of Dendroflora Agroforestry Systems, VNIALMI, Volgograd (2012).

[4] A.V. Semenyutina, I.Y. Podkovyrov, S.S. Taran, The Effectiveness of the Use of Cluster Method in the Analysis of the Merits of Ornamental Landscaping Plants, Global Scientific Potential, 40 (2014), 48-51.

[5] I.Y. Podkovyrov, T.M. Konotopskaya, Selection Estimation of hybrids of the Family Ulmaceae Mirb. for Ornamental Horticulture in Lower Volga Region, Russian Journal of Agricultural and Socio-Economic Research, 11 (2012), 28-32.

[6] A.V. Semenyutina, S.M. Kostyukov, Bioecological Justification Assortment Of Shrubs For Landscaping Urban Landscapes, Montreal (2013).

[7] A.S. Huzhahmetova, Models of CZK Species and Varieties of Hazelnut in the Age Aspect, Modern Problems of Science and Education, 3 (2015), 143.

[8] A.S. Huzhahmetova, Scientific Principles of Selection of Varieties and Study the Laws of Their Growth and Development, Taking into Account the Specifics of Climate, Modern Science: Actual Problems of Theory and Practice. Series of Natural and Technical Sciences, 9-10 (2014), 48-54.

[9] V.L. Chernih, N.A. Vlasov, N.G. Kiselyov, D.M. Vorozhtsov, Mathematical Methods in Forestry and Landscape Construction, Volga State Technological University Publ. House, Yoshkar-Ola (2011).

[10] A.V. Semenyutina, I.P. Svintsov, S.M. Kostyukov, The Gene Pool of Shrubs for Green Building, Nauka, Moscow (2016).

[11] A.V. Semenyutina, Dendroflora Agroforestry Systems, VNIALMI, Volgograd (2013).

[12] K.N. Kulik, A.V. Semenyutina, M.N. Belitskaya, I.Y. Podkovyrov, Modern problems and prospects of the functioning of the system of adaptive gardening, News of Nizhnevolzhsky Agrarian University Complex: Science and Higher Professional Education, 31 (2013), 4-29.

[13] A.V. Semenyutina, I.U. Podkovyrov, V.A. Semenyutina, Environmental Efficiency of the Cluster Method of Analysis of Greenery Objects Decorative Advantages, Life Science Journal, 12s (2014), 699-702.

[14] A.V. Semenyutina et al., Landscape Gardening in Rural Areas, VNIALMI, Volgograd (2014).

[15] K.N. Kulik, I.P. Svintsov, A.V. Semenyutina et al., Increasing of Biodiversity Shrubs in Recreation and Landscaping Plantings Arid Zone of Russia, Moscow (2008). 
[16] Y.I. Gilderman, Lectures on Higher Mathematics for Biologists, Nauka, Moscow (1974).

[17] V.L. Van der Waerden, Algebra, Nauka, Moscow (1976). 